\title{
Assessment of Tomato Hybrids for Yield and Quality Attributes under Protected Environment
}

\author{
Navjot Singh Dhillon ", Parveen Sharma, Pardeep Kumar and Vibhuti Sharma \\ Department of Vegetable Science and Floriculture, CSK HPKV, \\ Palampur-176062, (Himachal Pradesh), India \\ *Corresponding author
}

\section{A B S T R A C T}

\section{Keywords}

Hybrids, Polyhouse, Quality, Tomato, Yield

Article Info

Accepted: 04 April 2019 Available Online: 10 May 2019

\begin{abstract}
Experiment was conducted at Vegetable Research Farm, Department of Vegetable Science and Floriculture, CSK Himachal Pradesh Krishi Vishvavidyalaya, Palampur in springsummer season during 2016-17 to assess the yield and quality attributes of tomato hybrids under protected environment. The experiment was laid out in Randomized Block Design with three replications, consisting of ten hybrids of tomato and one standard check.12-1 $\times$ Palam Pride and 12-1 $\times$ BT-20-3 (Yellow Egg Shape) are good performing hybrids for yield related characters taken under study.12-1 $\times$ Palam Pride had maximum fruit yield per plant, fruit yield per meter square, number of fruits per plant, plant height and minimum days taken to $50 \%$ flowering and first picking followed by 12-1 × BT-20-3 (Yellow Egg Shape). For quality parameters BT-20-3 (Yellow Egg Shape) $\times$ Roma and BL 333-3 $\times$ Palam Pride were best. BT-20-3 (Yellow Egg Shape) $\times$ Roma had maximum pericarp thickness, TSS and also had higher ascorbic acid. Whereas BL 333-3 $\times$ Palam Pride had maximum ascorbic acid and higher titrable acidity.
\end{abstract}

\section{Introduction}

Tomato (Solanum lycopersicum L.) a member of Solanaceae family, is one of the most important vegetable crops grown widely all over the world. It is the most popular cultivated and versatile garden vegetable grown in the world (Kumar et al., 2013). It is well adapted to wide range of soils and climates and is grown from the tropics to the temperate areas. Its fruits are used in different food preparations and also preserved in different forms. Ripe fresh tomato fruit is consumed as salad and also utilized in the preparation of processed products such as puree, paste, powder, ketchup, sauce, soup and canned whole fruits. Unripe green fruits are used for preparation of pickles and chutney. Tomatoes are important source of lycopene (an antioxidant), ascorbic acid and $\beta$-carotene and valued for their colour and flavour. Lycopene is treasured for its anticancer attribute.

With the increasing zeal for its cultivation, the farmers are aptly looking towards improved varieties to meet out the higher standards of quality and quantity. Among tomato cultivars, hybrids have really brought the revolution in tomato cultivation. Not only the hybrids 
excelled in yield, tolerance to diseases, high adaptability to adverse environment, uniformity of produce and greater plant vigour but also have shown great potential to counter the challenge of high demand of fresh and processed products. Although a huge number of high yielding hybrids of tomato varying widely in respect to their yield potential, adaptability and response to inputs have been released for cultivation in open fields (Kaddi et al., 2014), yet the information on the performance of tomato hybrids under protected cultivation is meagre. Identification of hybrids suitable for protected cultivation, is therefore, most important. Hence, present investigation was conducted to study the comparative performance of to matohybrids for yield and quality characters under protected conditions.

\section{Materials and Methods}

The experiment was conducted under a modified naturally ventilated polyhouse having $250 \mathrm{~m}^{2}$ area at Experimental Farm of Department of Vegetable Science and Floriculture, CSK Himachal Pradesh Krishi Vishvavidyalaya, Palmpur during springsummer season in 2016-17.

The experimental material used for the present study comprised of 10hybrids of tomato and one standard check. The details of the hybrids and standard check are presented in Table 1.

Seeds of tomato hybrids were sown in plastic plug trays by using soilless media having cocopeat, perlite and vermiculite in the ratio of $3: 1: 1$, respectively inside the growth chamber to get healthy and disease free seedlings. The seedlings were ready for transplanting after 35 days. The experiment was laid out in a Randomized Block Design with three replications. The seedlings were transplanted at $70 \times 30 \mathrm{~cm}$ spacing. Regular irrigation, earthing up, fertilization, stacking and crop protection measures were adopted as per package of practices.

The observations were recorded on five plants taken randomly for the characters viz., days to $50 \%$ flowering, days to first picking, number of fruits/plant, fruit yield/plant $(\mathrm{kg})$, fruit yield $(\mathrm{kg}) / \mathrm{m}^{2}$ area, fruit shape index, pericarp thickness $(\mathrm{mm})$, inter-nodal length $(\mathrm{cm})$, plant height $(\mathrm{cm})$, TSS ( ${ }^{\circ}$ brix), ascorbic acid $(\mathrm{mg} / 100 \mathrm{gm})$ and titrable acidity (\%). For evaluation of quality parameters, ripe, firm and uniform tomatoes were taken. The data pertaining to the present investigation were statistical analyzed using the standard procedures of the Randomized Block Design (RBD) as described by Gomez and Gomez (1983).

\section{Results and Discussion}

Earliness is a desirable attribute, as the early crop produce invariably and fetches a higher price in the market. The perusal of data (Table 2) revealed that days to 50 per cent flowering ranged from 21.67 to 30.67 days. $\mathrm{T}_{6}$ took minimum days to reach 50 percent flowering which was statically at par with $\mathrm{T}_{7}$. Three hybrids were significantly earlier to standard check hybrid ArkaRakshak. Sharma (2003), Kumar et al., (2012) and Kayess et al., (2017) also observed most of the tomato hybrids earlier to the standard check. Days to first picking ranged from 67.54 to 87.40 days. $\mathrm{T}_{6}$ took minimum days to first picking which was statically at par with $T_{7}$ and $T_{8}$. Two hybrids were significantly earlier to standard check hybrid ArkaRakshak. Chibi et al., (2015) and Dhyani et al., 2017 have also reported similar results.

Number of fruits per plant is the most important component trait which is directly related to increased fruit yield per plant. Comparison of the mean values revealed that 
the number of fruits per plant ranged from 25.06 to 39.56 . $\mathrm{T}_{6}$ has maximum number of fruits per plant which was statically at par with $\mathrm{T}_{7}$.Five hybrids produced significantly higher number of fruits per plant than the standard check. Earlier researchers (Islam et al., 2012; Marbhal et al., 2016; Kyess et al., 2017; Vijeth et al., 2018) have also reported majority of the hybrids surpassing the controls/standard check for total number of fruits per plant in their studies.

The ultimate goal of any research programme is to achieve maximization of marketable yield. This is also the key factor in adoption or rejection of a hybrid by the farmer. The fruit yield per plant and fruit yield per meter square ranged from 1.72 to $2.88 \mathrm{~kg}$ and 10.32 to $17.28 \mathrm{~kg}$, respectively. Significantly maximum value for these traits was noticed in $\mathrm{T}_{6}$. Three hybrids gave significantly higher fruit yield per plant as compared to the standard check. Sharma (2003), Dhaliwal and Cheema (2011), Kumar et al., (2012), Cheema et al., (2013), Dhyani et al., (2017), Kayess et al., (2017) and Vijeth et al., (2018) have also reported that the hybrids excelling the control/standard check in total fruit/gross yield per plant.

Fruit shape index value ranged from 0.83 to 1.21. Five hybrids had significantly higher fruit shape index as compared to the standard check (ArkaRakshak). Six hybrids produced oval fruits (fruit shape index $\geq 1$ ), three hybrids and standard check (ArkaRakshak) produced spherical fruits with fruit shape index ranging from 0.86 to 0.99 .

Only one hybrid produced intermediate fruits with flat round shape (fruit shape index 0.71 to 0.85). Joshi et al., (2005), Dhyani et al., (2017) and Kayess et al., (2017) have also observed number of hybrids surpassing the standard check for fruit shape index.
The improved shelf-life resulting from thicker pericarp helps in reducing post-harvest losses. Thicker pericarp also helps in long distance transport of tomatoes with minimal transportation injuries. Pericarp thickness ranged from $6.20 \mathrm{~mm}$ to $8.32 \mathrm{~mm}$ (Table 3). The maximum pericarp thickness was recorded in $\mathrm{T}_{10}$ which was statically at par with $\mathrm{T}_{5}$ and $\mathrm{T}_{9}$. Three hybrids produced significantly higher pericarp thickness than the standard check. The present findings are in line with Makesh et al., (2003), Chattopadhyay and Paul (2012), Cheema et al., (2013) and Dhyani et al., (2017).

Internodal length determines the height and number of nodes/plant. Plants having less inter-nodal length and more number of nodes have desired for getting higher yield. The internodal length ranged from 6.50 to $13.96 \mathrm{~cm}$. The minimum value for internodal length was noticed in standard check (ArkaRakshak) which was statistically at par with $\mathrm{T}_{10}$. Earlier researchers viz., Chaudhary and Malhotra (2001) and Dhyani et al., (2017) have also reported minimum internodal length in the standard check as compare to other hybrids. Indeterminate type of hybrids is preferred over semi-determinate and determinate types in high rainfall area under mid Himalayan conditions, where the fruiting period invariably coincides with heavy rainfall, causing huge losses to fruits due to fruit rot disease. Determinate and semideterminate types of genotypes experience more infestation of the disease than indeterminate varieties. Plant height $(\mathrm{cm})$ ranged from 110.27 to 292.00. The maximum plant height was significantly noticed in $\mathrm{T}_{10}$ and significantly minimum was in check (ArkaRakshak). The present findings are contrary to those of Kumar et al., (2012) could not report any of the hybrids in their studies which could surpass the standard check in plant height. Cheema et al., (2013) reported 4 out of 28 hybrids have significantly 
higher plant height as compared to the standard check Avtar (7711). While Fageria et al., (2001) and Kayess et al., (2017) reported about 20-40 per cent of the hybrids in their experiments exceeding the standard check variety in plant height.

The total content of soluble solids on fruits (TSS) is a key trait, as it influences final product flavor and consistency, and ultimately determines the final yield after processing. Table 3 depict that total soluble solids ranged from 4.44 to $5.26^{\circ}$ Brix. The mean performance for this trait was non-significant. Ascorbic acid is of much importance from nutrition point of view due to its antioxidant property.

Table.1 List of tomato (Solanum lycopersicum L.) hybrids and standard check used in the study

\begin{tabular}{|c|l|}
\hline Code No. & \multicolumn{1}{|c|}{ Hybrids } \\
\hline $\mathbf{T}_{\mathbf{1}}$ & BL 333-3 $\times$ CLN 2123 \\
\hline $\mathbf{T}_{\mathbf{2}}$ & BL 333-3 $\times$ 12-1 \\
\hline $\mathbf{T}_{\mathbf{3}}$ & BL 333-3 $\times$ Palam Pride \\
\hline $\mathbf{T}_{\mathbf{4}}$ & CLN 2123 $\times$ Punjab Chhuhara \\
\hline $\mathbf{T}_{\mathbf{5}}$ & CLN 2123 $\times$ Roma \\
\hline $\mathbf{T}_{\mathbf{6}}$ & $12-1 \times$ Palam Pride \\
\hline $\mathbf{T}_{\mathbf{7}}$ & $12-1 \times$ BT-20-3 (Yellow Egg Shape) \\
\hline $\mathbf{T}_{\mathbf{8}}$ & Palam Pride $\times$ Roma \\
\hline $\mathbf{T}_{\mathbf{9}}$ & Bt-20-3 (Yellow Egg Shape) $\times$ Punjab Chhuhara \\
\hline $\mathbf{T}_{\mathbf{1 0}}$ & Bt-20-3 (Yellow Egg Shape) $\times$ Roma \\
\hline $\mathbf{C h e c k}$ & ArkaRakshak \\
\hline
\end{tabular}

Table.2 Mean performance of tomato hybrids and standard check for yield and quality characters

\begin{tabular}{|c|c|c|c|c|c|c|}
\hline Treatments & $\begin{array}{c}\text { Days to } \\
\mathbf{5 0 \%} \\
\text { flowering }\end{array}$ & $\begin{array}{c}\text { Days to } \\
\text { first } \\
\text { picking }\end{array}$ & $\begin{array}{c}\text { Number of } \\
\text { fruits per } \\
\text { plant }\end{array}$ & $\begin{array}{c}\text { Fruit yield } \\
\text { per plant } \\
\text { (Kg) }\end{array}$ & $\begin{array}{c}\text { Fruit yield } \\
\text { per meter } \\
\text { square } \\
\left(\mathbf{K g} / \mathbf{m}^{2}\right)\end{array}$ & $\begin{array}{c}\text { Fruit } \\
\text { shape } \\
\text { index }\end{array}$ \\
\hline $\mathbf{T}_{\mathbf{1}}$ & 26.67 & 80.21 & 34.89 & 2.43 & 14.56 & 1.00 \\
\hline $\mathbf{T}_{\mathbf{2}}$ & 27.67 & 77.84 & 33.37 & 2.02 & 12.10 & 0.93 \\
\hline $\mathbf{T}_{\mathbf{3}}$ & 30.67 & 81.90 & 31.52 & 2.09 & 12.54 & 0.96 \\
\hline $\mathbf{T}_{\mathbf{4}}$ & 30.00 & 87.40 & 25.06 & 1.86 & 11.16 & 1.09 \\
\hline $\mathbf{T}_{\mathbf{5}}$ & 28.67 & 81.21 & 26.16 & 1.93 & 11.60 & 1.21 \\
\hline $\mathbf{T}_{\mathbf{6}}$ & 21.67 & 67.54 & 39.56 & 2.88 & 17.28 & 1.13 \\
\hline $\mathbf{T}_{\mathbf{7}}$ & 23.67 & 70.79 & 36.68 & 2.54 & 15.26 & 0.83 \\
\hline $\mathbf{T}_{\mathbf{8}}$ & 26.00 & 73.09 & 25.73 & 1.94 & 11.62 & 0.87 \\
\hline $\mathbf{T}_{\mathbf{9}}$ & 26.67 & 81.49 & 25.80 & 1.72 & 10.32 & 1.21 \\
\hline $\mathbf{T}_{\mathbf{1 0}}$ & 27.67 & 82.90 & 25.25 & 1.83 & 10.96 & 1.19 \\
\hline $\mathbf{C h e c k}$ & 29.22 & 80.28 & 25.38 & 1.97 & 11.82 & 0.91 \\
\hline $\mathbf{C D} \mathbf{p}=\mathbf{. 0 5})$ & 3.21 & 7.21 & 3.68 & 0.22 & 1.30 & 0.11 \\
\hline
\end{tabular}


Table.3 Mean performance of tomato hybrids and standard check for growth and quality characters

\begin{tabular}{|c|c|c|c|c|c|c|}
\hline Treatments & $\begin{array}{c}\text { Pericarp } \\
\text { thickness } \\
\text { (mm) }\end{array}$ & $\begin{array}{c}\text { Internodal } \\
\text { length }(\mathbf{c m})\end{array}$ & $\begin{array}{c}\text { Plant } \\
\text { height } \\
\mathbf{( c m})\end{array}$ & $\begin{array}{c}\text { TSS } \\
\left({ }^{\mathbf{o}} \mathbf{B r i x}\right)\end{array}$ & $\begin{array}{c}\text { Ascorbic acid } \\
\text { (mg/100gm) }\end{array}$ & $\begin{array}{c}\text { Titrable } \\
\text { acidity } \\
(\mathbf{\%})\end{array}$ \\
\hline $\mathbf{T}_{\mathbf{1}}$ & 7.51 & 13.00 & 179.25 & 4.72 & 22.77 & 0.62 \\
\hline $\mathbf{T}_{\mathbf{2}}$ & 6.81 & 13.77 & 229.62 & 5.24 & 24.72 & 0.79 \\
\hline $\mathbf{T}_{\mathbf{3}}$ & 6.20 & 13.26 & 209.80 & 4.44 & 26.52 & 0.81 \\
\hline $\mathbf{T}_{\mathbf{4}}$ & 7.22 & 12.09 & 131.96 & 4.80 & 21.54 & 0.82 \\
\hline $\mathbf{T}_{\mathbf{5}}$ & 7.88 & 10.85 & 124.95 & 5.04 & 22.77 & 0.73 \\
\hline $\mathbf{T}_{\mathbf{6}}$ & 7.12 & 13.70 & 292.00 & 4.98 & 25.40 & 0.55 \\
\hline $\mathbf{T}_{\mathbf{7}}$ & 7.11 & 13.96 & 276.29 & 5.09 & 23.25 & 0.51 \\
\hline $\mathbf{T}_{\mathbf{8}}$ & 6.93 & 9.54 & 130.22 & 4.60 & 22.13 & 0.73 \\
\hline $\mathbf{T}_{\mathbf{9}}$ & 8.13 & 12.27 & 143.96 & 4.88 & 22.46 & 0.61 \\
\hline $\mathbf{T}_{\mathbf{1 0}}$ & 8.32 & 7.47 & 130.43 & 5.26 & 24.63 & 0.65 \\
\hline $\mathbf{C h e c k}$ & 7.19 & 6.50 & 110.27 & 5.02 & 24.93 & 0.51 \\
\hline $\mathbf{C D}(\mathbf{p = . 0 5})$ & 0.67 & 1.15 & 7.46 & NS & 2.47 & 0.06 \\
\hline
\end{tabular}

Comparison of the mean values for ascorbic acid content among hybrids indicated that ascorbic acid content ranged from 21.54 to $26.52 \mathrm{mg} / 100 \mathrm{~g} . \mathrm{T}_{3}$ had maximum value which was statically at par with $\mathrm{T}_{2}, \mathrm{~T}_{6}, \mathrm{~T}_{10}$ and standard check. Makesh et al., (2003), Anita et al., (2005), Kumari and Sharma (2011), Cheema et al., (2013), Kumar et al., (2013) and Vijeth et al., (2018) also find similar results.

Higher acidity is important for processing industry, while fruits with low acidity are preferred for fresh table use. Hence, fruits with both kinds carry value in the market. The titrable acidity ranged from 0.51 to 0.82 per cent. The maximum value for titrable acidity was noticed in $T_{4}$ which was statistically at par with $T_{2}$ and $T_{3}$.Eight hybrids had significantly higher titrable acidity than the standard check. Makesh et al., (2003), Cheema et al., (2013), Kumar et al., (2013) and Vijeth et al., (2018) have also reported that the hybrid mean was more than the standard check.
Based upon the present study, it can be concluded that $\mathrm{T}_{6}(12-1 \times$ Palam Pride $)$ and $\mathrm{T}_{7}$ (12-1 × BT-20-3 (Yellow Egg Shape))are good performing hybrids for yield related characters taken under study. $\mathrm{T}_{6}(12-1 \times$ Palam Pride) had maximum fruit yield per plant, fruit yield per meter square, number of fruits per plant, plant height and minimum days taken to $50 \%$ flowering and first picking followed by $\mathrm{T}_{7}$ [12-1 $\times$ BT-20-3 (Yellow Egg Shape)]. For quality parameters $\mathrm{T}_{10}$ [BT-20-3 (Yellow Egg Shape) $\times$ Roma] and $\mathrm{T}_{3}(\mathrm{BL} 333-$ $3 \times$ Palam Pride) were best. $\mathrm{T}_{10}$ [BT-20-3 (Yellow Egg Shape) $\times$ Roma] had maximum pericarp thickness, TSS and also had higher ascorbic acid. Whereas $\mathrm{T}_{3}(\mathrm{BL} 333-3 \times$ Palam Pride) had maximum ascorbic acid and higher titrable acidity.

\section{References}

Anita, S., Gautam, J.P.S., Upadhyay, M., and Joshi, A. 2005. Heterosis for yield and quality characters in tomato. Crop Research. 29: 285-287.

Chattopadhyay, A., and Paul, A., 2012. 
Studies on heterosis for different fruit quality parameters in tomato. International Journal of Agriculture, Environment and Biotechnology. 5: 405-410.

Chaudhary, D.R., and Malhotra, S.K., 2001. Studies on hybrid vigour in tomato (Lycopersicon esculentum Mill.). Indian Journal of Agricultural Research. 35(3): 176-180.

Cheema, D.S., Singh, N. and Jindal, S.K. 2013. Evaluation of indeterminate tomato hybrids for fruit, yield and quality traits under net house and open field conditions. Vegetable Science. 40(1): 45-49.

Chibi, F.I., Mushayabasa, T. and Magejo, E. 2015. Evaluation of hybrid indeterminate tomato (Solanum lycopersicum L.) varieties for commercial greenhouse production. Annals of Biological Research. 6(6):65-68.

Dhaliwal, M.S., and Cheema, D.S. 2011. Genetic analysis of fruit weight and total yield in tomato and development of $F_{1}$ hybrids for cultivation under leaf curl virus infested conditions. Crop Improvement. 38: 60-66.

Dhyani, S., Misra, A.C., Panday, V. and Sajwan, P. 2017. Evaluation of tomato (Solanum lycopersicon L.) hybrids for fruit yield characters in Hill Region of Uttarakhand, India. International Journal of Current Microbiology and Applied Sciences, 6(9): 1622-1633.

Fageria, M.S., Kohli, U.K., and Dhaka, R.S., 2001. Studies on heterobeltiosis for fruit yield and yield attributing traits in tomato (Lycopersicon esculentum Mill.). Haryana Journal of Horticultural Sciences. 30: 131-133.

Islam, M.R., Ahmad, S., and Rahman, M.M. 2012. Heterosis and qualitative attributes in winter tomato (Solanum lycopersicum L.) hybrids. Bangladesh
Journal of Agricultural Research. 37: 39-48.

Joshi, A., Thakur, M.C., and Kohli, U.K. 2005. Heterosis and combining ability for shelf life, whole fruit firmness and related traits in tomato. Indian Journal of Horticulture. 62: 33-36.

Kaddi, G., Tomar, B.S., Singh, B., and Kumar, S. 2014. Effect of growing conditions on seed yield and quality of cucumber (Cucumis sativus) hybrid. Indian Journal of Agricultural Sciences.84: 624-627.

Kayess, M.O., Uddin, M.J., Hasanuzzaman, M., Rahman, M.I. and Alam, M.R. 2017. Performance evaluation of some productive tomato (Lycopersicon esculentum Mill.) hybrids. International Journal of Biosciences. 10(1): 279-284.

Kumar, M., Tanuja, B., Mohar, S.T. and Thakur, K.S. 2013. Genetic divergence and cluster analysis in tomato (Solanum lycopersicum L.). Progressive Agriculture. 13: 114-117.

Kumar, R., Srivastava, K., Somappa, J., Kumar, S. and Singh, R.K. 2012. Heterosis for yield and yield components in tomato (Lycopersicon esculentum Mill). Electronic Journal of Plant Breeding. 3: 800-805.

Kumar, V., Nandan, R., Sharma, S.K., Srivastava, Kumar, R. and Singh, M.K. 2013. Heterosis study for quality attributing traits in different crosses in tomato (Solanum lycopersicum L.). Plant Archives. 13: 21-26.

Kumari, S., and Sharma, M.K. 2011. Exploitation of heterosis for yield and its contributing traits in tomato (Solanum lycopersicum L.). International Journal of Farm Sciences. 1: 45-55.

Makesh, S., Jebaraj, S., and Ashok, S., 2003. Per se performance of parents and hybrids in tomato for quantitative and 
qualitative characters. Madras Agricultural Journal. 90: 20-24.

Marbhal, S.K., Ranpise, S.A., and Kshirsagar, D.B. 2016. Heterosis study in tomato for quantitative traits. International Research Journal of Multidisciplinary Studies. 2(2): 1-6.

Sharma, K.C., Verma, S. and Pathak, S. 2003. Combining ability and gene action studies for earliness in tomato
(Lycopersicon esculentum Mill.). Vegetable Science. 30: 89-90.

Vijeth, S., Dhaliwal, M.S, Jindal, S.K and Sharma, A. 2018. Evaluation of tomato hybrids for resistance to leaf curl virus disease and for high yield production. Horticulture, Environment, and Biotechnology. 59(5): 699-709.

\section{How to cite this article:}

Navjot Singh Dhillon, Parveen Sharma, Pardeep Kumar and Vibhuti Sharma. 2019. Assessment of Tomato Hybrids for Yield and Quality Attributes under Protected Environment. Int.J.Curr.Microbiol.App.Sci. 8(05): 256-262. doi: https://doi.org/10.20546/ijcmas.2019.805.029 